\title{
Development and Design of a Multi-column Experimental Setup for Kr/Xe Separation \\ Fuel Cycle Technology
}

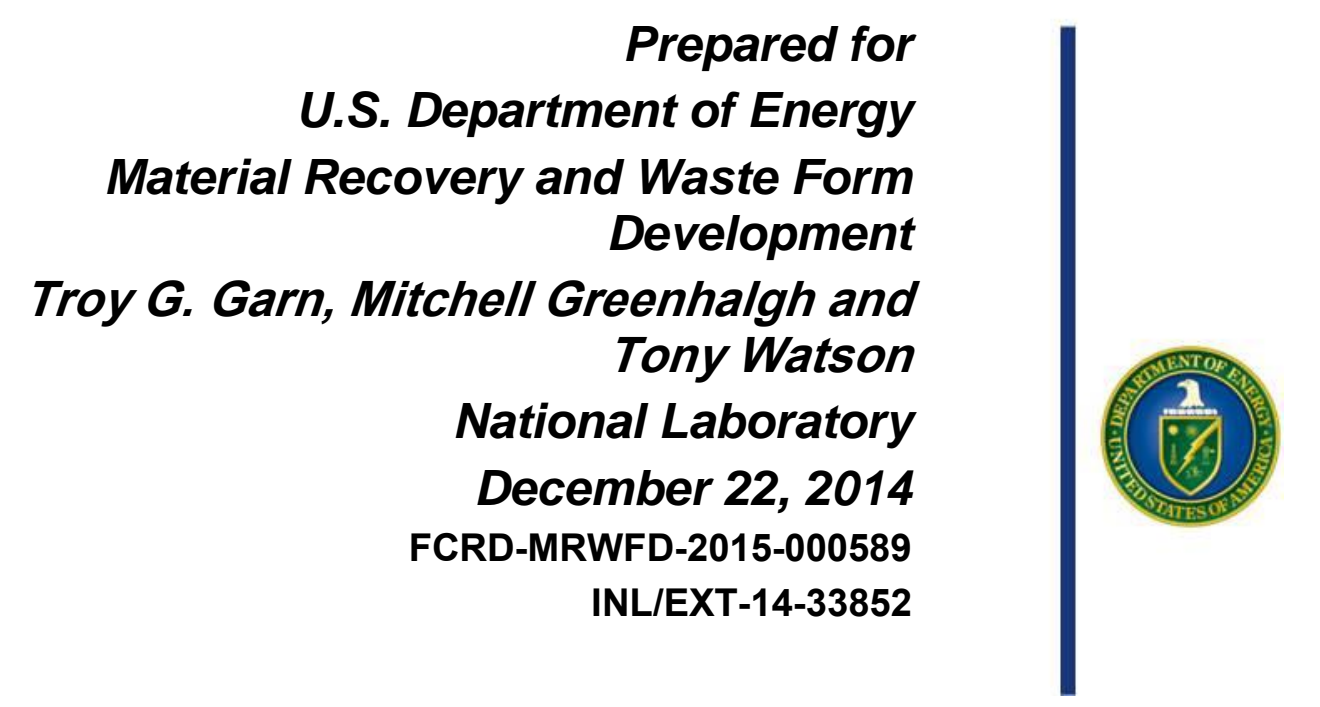





\section{DISCLAIMER}

This information was prepared as an account of work sponsored by an agency of the U.S. Government. Neither the U.S. Government nor any agency thereof, nor any of their employees, makes any warranty, expressed or implied, or assumes any legal liability or responsibility for the accuracy, completeness, or usefulness, of any information, apparatus, product, or process disclosed, or represents that its use would not infringe privately owned rights. References herein to any specific commercial product, process, or service by trade name, trade mark, manufacturer, or otherwise, does not necessarily constitute or imply its endorsement, recommendation, or favoring by the U.S. Government or any agency thereof. The views and opinions of authors expressed herein do not necessarily state or reflect those of the U.S. Government or any agency thereof. 



\section{SUMMARY}

As a precursor to $\mathrm{FY}-15 \mathrm{Kr} / \mathrm{Xe}$ separation testing, design modifications to an existing experimental setup are warranted. The modifications would allow for multi-column testing to facilitate a Xe separation followed by a $\mathrm{Kr}$ separation using engineered form sorbents.

A new cooling apparatus capable of achieving test temperatures to $40^{\circ} \mathrm{C}$ and able to house a newly designed Xe column was acquired. Modifications to the existing setup are being installed to allow for multi-column testing and gas constituent analyses using evacuated sample bombs.

The new modifications will allow for independent temperature control for each column enabling a plethora of test conditions to be implemented. Sample analyses will be used to evaluate the $\mathrm{Xe} / \mathrm{Kr}$ selectivity of the AgZ-PAN sorbent and determine the $\mathrm{Kr}$ purity of the effluent stream following $\mathrm{Kr}$ capture using the HZ-PAN sorbent. 


\section{CONTENTS}

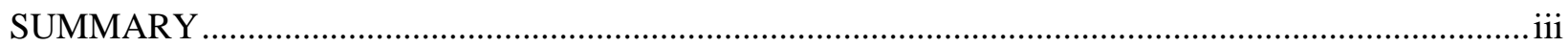

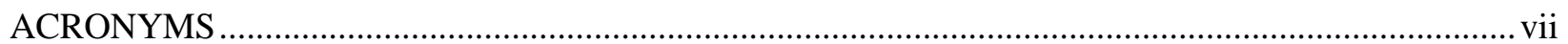

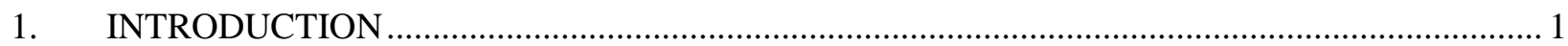

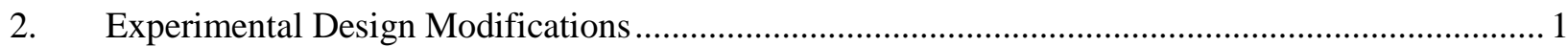

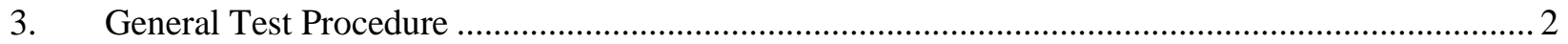

\section{FIGURES}

Figure 1. Conceptual design for a multi-column experimental setup ................................................2

\section{TABLES}

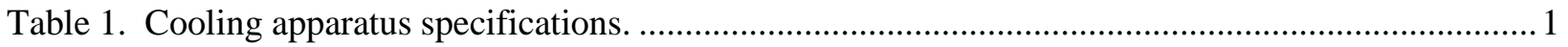




\section{ACRONYMS}

AgZ-PAN Silver converted mordenite engineered form

HZ-PAN Hydrogen mordenite engineered form

GC-TCD Gas Chromatograph with thermal conductivity detector

GC-MS Gas Chromatograph with Mass Spectrometer 


\section{DEVELOPMENT AND DESIGN OF A MULTI-COLUMN EXPERIMENTAL SETUP FOR KR/XE SEPARATION}

\section{INTRODUCTION}

The ability to separate $\mathrm{Kr}$ from other components present in used nuclear fuel reprocessing off-gas streams is necessary to meet the current radioactive emissions limits and would also reduce the final volume of $\mathrm{Kr}$ waste being released. By utilizing simplified physisorption techniques, Xe can be separated from $\mathrm{Kr}$ resulting in a highly pure $\mathrm{Kr}$ final product. In addition, an economic benefit over cryogenic distillation may be realized.

A patented procedure developed at INL has resulted in the ability to prepare engineered form sorbents consisting of bound mordenite powders in a macroporous polymer. Previous testing has indicated that a hydrogen form mordenite (HZ-PAN) can be used to effectively capture $\mathrm{Kr}$ at reduced temperatures $(\approx-$ $80^{\circ} \mathrm{C}$ ) and a silver converted form mordenite (AgZ-PAN) has shown selectivity for Xe over $\mathrm{Kr}$ at or near room temperature $\left(20\right.$ to $\left.{ }^{-} 20^{\circ} \mathrm{C}\right)$.

In support of a FY-15 level 2 milestone to evaluate the potential for capturing a purified $\mathrm{Kr}$ gas product using physisorption techniques, modifications to the existing test setup incorporating a multi-column test bed have been initiated. The multi-column design will allow for testing of the two engineered forms, as well as other sorbents developed by the Off-Gas Sigma Team, at varying temperatures to determine the ability to separate $\mathrm{Xe}$ from $\mathrm{Kr}$ and ultimately determine the $\mathrm{Kr}$ purity of the final product stream.

The purpose of this document is to describe the design modifications incorporated into the original experimental test setup. The modified setup will be used for FY-15 testing. Results of this testing will be documented in the level 2 milestone report due August 31, 2015.

\section{Experimental Design Modifications}

There are two primary challenges driving design modification decisions which include; 1) ability to control the Xe column (AgZ-PAN) temperature for adsorption cooling and desorption heating, and 2) capture the adsorbed gases for composition analyses. The first challenge was met by acquiring a cooling apparatus capable of housing a column and tightly controlling the temperature down to a minimum of $40^{\circ} \mathrm{C}$ and allowing heating of the column to desorb the captured constituents. Specifications for the cooling apparatus are found in Table 1. To determine product stream compositions, sample ports will be installed to accept connection of evacuated and volume calibrated gas sample bombs. The adsorbed gases will be transferred to the sample bombs and then analyzed via GC-MS for $\mathrm{Kr}$ and Xe concentrations.

Table 1. Cooling apparatus specifications.

\begin{tabular}{c|l} 
Make/model & Stirling Ultra Low temperature freezer/ShuttleC ULT:25N \\
\hline Cooling temperature range & $-86^{\circ} \mathrm{C}$ to $20^{\circ} \mathrm{C} @ 32^{\circ} \mathrm{C}\left(90^{\circ} \mathrm{F}\right)$ ambient, uniformity $\pm 0.75^{\circ} \mathrm{C}$ \\
\hline Specifications & $\begin{array}{l}\text { Ambient operating temperature }+5^{\circ} \mathrm{C} \text { to }+35^{\circ} \mathrm{C}\left(41^{\circ} \mathrm{F} \text { to } 95^{\circ} \mathrm{F}\right) \\
\text { Refrigerant, R-508B non-flammable CFC/HCFC-Free } \\
\text { Cooling engine- Humm helium charge free-piston Stirling engine with } \\
\text { continuous modulation } \\
\text { Electrical Power } 120 \mathrm{~V} \text { AC or } 12 \mathrm{~V} \text { DC from mobile source }\end{array}$ \\
\hline
\end{tabular}


Initial efforts to design and construct a new Xe column have been completed. The column needs to be adequately sized to contain enough sorbent to run for a sufficient amount of time to provide measurable $\mathrm{Kr}$ concentrations to the HZ-PAN column but small enough to fit inside the cooling apparatus. Column sizing design incorporated Xe breakthrough data determined from previous testing at room temperature i.e. lowest capacities measured. The final size dimensions of the Xe column will be 0.75 in. O.D. $x 9$ in. long stainless steel cylinder. The $50 \mathrm{~cm}^{3}$ volume will house roughly 20 grams of AgZ-PAN material with a bulk density of $\sim 0.4 \mathrm{~g} / \mathrm{cm}^{3}$. The column will incorporate three thermowells for thermocouple insertion to monitor internal sorbent temperature.

The preliminary conceptual design for the multi-column experimental test setup is shown in Figure 1. The conceptual design allows for gas flow initiated from the test gases through both columns, through either column or bypassing the columns. All flow can be routed through the GC-TCD in any valve lineup configuration. Locations for sample bomb connections are also shown.

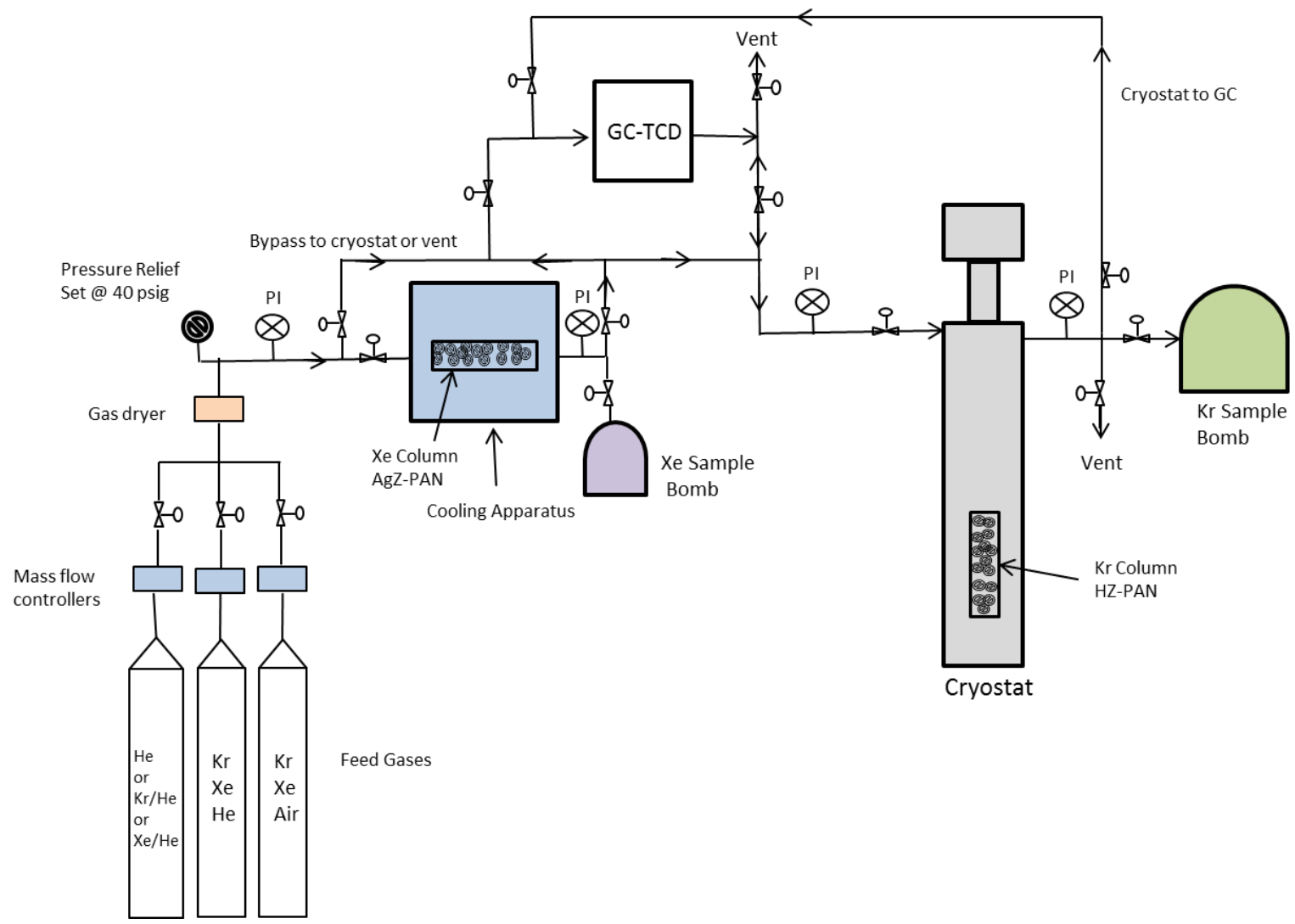

Figure 1. Conceptual design for a multi-column experimental setup.

\section{General Test Procedure}

The primary purpose of this testing is to determine the purity of $\mathrm{Kr}$ gas captured by the HZ-PAN sorbent. Initial testing will start by establishing desired temperatures for both columns followed by flowing selected test gases through the setup. The GC-TCD will be used to monitor for Xe, specifically to indicate when Xe breaks through the column in the cooling apparatus. The test gas flow would then be stopped and the sample bombs will be connected to the column effluent lines. Following an appropriate valve lineup, the gas contained in the columns will be pulled into the evacuated sample bombs. The bombs will be removed and the constituents will be analyzed via GC-MS (not shown in Figure) for Xe and $\mathrm{Kr}$ concentrations. Numerous tests are planned to evaluate $\mathrm{Xe}$ and $\mathrm{Kr}$ capacities for both sorbents at 
varying temperature and feed gas concentrations. Preliminary $\mathrm{Xe} / \mathrm{Kr}$ selectivity tests will be completed using AgZ-PAN to provide runtime information and indication of selectivity at varying temperatures. Future tests are also planned to evaluate Ni-DOBDC MOF materials in this newly constructed multicolumn test bed. 